\title{
Perioperative intra- venous flurbiprofen reduces postoperative pain after abdominal hysterectomy
}

\author{
M asayasu $\mathrm{N}$ akayama M $\mathrm{D}, *$ \\ $\mathrm{H}$ iromichi I chinose $M D^{*}$, \\ Shuji Yamamoto MD,* \\ Ken-ichi $\mathrm{N}$ akabayashi MD,* \\ O samu Satoh M D,* \\ Akiyoshi N amiki MD PhD $\dagger$
}

Purpose: To assess whether perio perative intravenous administration of flurbiprofen, a non-stero idal anti-inflammatory drug, reduced postoperative pain after abdominal hysterectomy.

Methods: Forty-five patients undergoing abdominal hysterectomy were randomly assigned to one of three groups of equal size. A control group (CONT) received a placebo $30 \mathrm{~min}$ before and at the end of surgery. The other two groups, PRE and PO ST, received $1 \mathrm{mg} \cdot \mathrm{kg}^{-1}$ flurbiprofen iv 30 min before and at the end of surgery, respectively. All patients received identical general and epidural anesthesia. Postoperatively, $50 \mathrm{mg}$ diclo fenac $\mathrm{pr}$ was given for pain relief on patient demand. 0 ne of the authors assessed pain using a $10 \mathrm{~cm}$ visual analog scale at rest and during coughing at the first request for diclofenac, and at 15, 24, 48, and $72 \mathrm{hr}$ after surgery. The number of times diclofenac was required during the first $24 \mathrm{hr}$ after surgery was also recorded.

Results: The number of diclo fenac requests in the PRE $(1.8 \pm 0.4)$ and PO ST groups $(2.0 \pm 0.4)$ were less than in the CONT group $(3.0 \pm 0.4)$. The PRE group showed lower visual analog scale at rest at 15 and $24 \mathrm{hr}$ and on coughing at 24,48 , and $72 \mathrm{hr}$ after surgery than the CONT and POST groups.

Conclusion: Intravenous $1 \mathrm{mg} \cdot \mathrm{kg}^{-1}$ flurbiprofen administered during anesthesia reduces postoperative rescue analgesic requirement after abdominal hysterectomy. Moreover, flurbiprofen is more effective when given before than after surgery.

O bjectif : Vérifier si l'administration intraveineuse périopératoire de flurbiprofène, un anti-inflammatoire non stéroïdien, réduit la douleur postopératoire d'une hystérectomie abdominale.

M éthode : Q uarante-cinq patientes devant subir une hystérectomie abdominale ont été réparties au hasard en trois groupes égaux. Un groupe témoin (TEM) a reçu un placebo, 30 min avant et à la fin de l'o pération. Les deux autres groupes, PRE et PO ST, ont reçu $1 \mathrm{mg} \cdot \mathrm{kg}^{-1}$ de flurbiprofène iv $30 \mathrm{~min}$ avant et à la fin de l'intervention, respectivement. Toutes les patientes ont reçu une anesthésie générale et épidurale identique. Après l'intervention, $50 \mathrm{mg}$ de diclofénac pr ont été administrés sur demande comme analgésie. Un des auteurs a évalué la douleur en utilisant une échelle visuelle analo gique de $10 \mathrm{~cm}$, au repos et pendant la toux à la première demande de diclofénac et, puis à $15,24,48$ et $72 \mathrm{~h}$ après l'opération. $0 \mathrm{n}$ a aussi noté le nombre de demandes de diclofénac pendant les 24 premières heures postopératoires.

Résultats : Les demandes de diclofénac dans les groupes PRE $(1,8 \pm 0,4)$ et POST $(2,0 \pm 0,4)$ ont été moins nombreuses que dans le groupe TEM $(3,0 \pm 0,4)$. Le groupe PRE a donné des scores plus bas à l'EVA au repos à 15 et $24 \mathrm{~h}$ et lors de la toux à 24,48 , et $72 \mathrm{~h}$ après l'intervention, en comparaison avec les groupes TEM et POST.

Conclusion : L'administration intraveineuse de $1 \mathrm{mg} \cdot \mathrm{kg}^{-1}$ de flurbiprofène pendant l'anesthésie réduit les besoins d'analgésie postopératoire à la suite d'une hystérectomie abdominale. De plus, le flurbiprofène est plus efficace lorsqu'on l'administre avant qu'après l'intervention chirurgicale.

From the Division of Anesthesia, O bihiro Kosei H ospital,* O bihiro, and Sapporo M edical U niversity School of M edicine, $\dagger$ Sapporo, Japan. A ddress correspondence to: D r. M . N akayama, D ivision of Anesthesia, O bihiro Kosei H ospital, West-6, South-8-1, O bihiro 080-0016, Japan. Phone: +0155/ 24-4161; Fax: +0155/ 25-7851; E-mail: miyabi@zc4.so-net.ne.jp A ccepted for publication N ovember 18, 2000. 
$\mathrm{N}$

ON-STEROIDAL anti-inflammatory drugs (NSAIDS) provide postoperative pain relief after different types of surgery. ${ }^{1,2}$ Flurbiprofen, an injectable NSAID, is an effective and safe analgesic when the parenteral route is required. . $^{3,4}$

Pre-emptive analgesia decreases the growth of pain when antinociceptive treatment is given before noxious stimulation because it prevents the establishment of central sensitization. ${ }^{5}$ The preemptive efficacy of N SAID s is controversial: not all studies have reported benefit. ${ }^{5-8}$ We investigated whether flurbiprofen iv, given in a preemptive manner, reduce postoperative pain after abdominal hysterectomy .

$M$ aterial and methods

After institutional approval and informed consent, we studied 45 ASA physical status I women, 40 to 60 -yrold, undergoing elective abdominal hysterectomy (vertical lower abdominal incision) because of myoma of the uterus. Patients who suffered from chronic pain were excluded from the study. Before surgery, each patient was instructed in the evaluation of pain using the visual analog scores using a ruler (VAS; $0 \mathrm{~cm}=$ no pain to $10 \mathrm{~cm}=$ the worst possible pain).

Patients were premedicated with 3-4 mg midazolam i 30 min before arrival in the operating room. They received at least $500 \mathrm{ml}$ acetated Ringer's solution before anesthesia. The ECG and hemoglobin oxygen saturation were monitored continuously, and arterial pressure was measured automatically by an oscillographic method every five minutes. An epidural catheter was placed through an 18-G auge Tuohy needle using the loss of resistance technique at the $\mathrm{T}_{11-12}$ interspace, and tested with $2 \mathrm{ml}$ lidocaine $1.5 \%$ with $1: 200,000$ epinephrine followed by $10 \mathrm{ml}$ of the same lidocaine solution. General anesthesia was induced with $3 \mathrm{mg} \cdot \mathrm{kg}^{-1}$ thiamylal iv, and tracheal intubation was facilitated with $0.1 \mathrm{mg} \cdot \mathrm{kg}^{-1}$ vecuronium iv. Anesthesia was maintained with sevoflurane $1 \%$ to $2 \%$, nitrous oxide $67 \%$ in oxygen, and with epidural block using lidocainel.5\% At the time of wound closure, 5 $\mathrm{ml}$ bupivacaine $0.25 \%$ were administered through the epidural catheter. The catheter was removed in the operating room. Narcotics were not used either parenterally or epidurally during the study period.

Patients were randomly assigned, via sealed envelope assignment, to one of three groups of equal size. The CONT group received Intralipid $₫$ as placebo 30 min before and at the end of surgery. The PRE group received $1 \mathrm{mg} \cdot \mathrm{kg}^{-1}$ flurbiprofen iv $30 \mathrm{~min}$ before surgery and a placebo at the end of surgery. The POST group received a placebo 30 min before surgery and flurbiprofen at the end of surgery. The placebo and flurbiprofen were mixed with $100 \mathrm{ml}$ saline and given over $15 \mathrm{~min}$. This test solution was prepared by one anesthesiologist, and another anesthesiologist who was blinded to the solution performed anesthesia. Both placebo and the flurbiprofen solution looked the same.

For postoperative pain relief, diclofenac suppository was administered in increments of $50 \mathrm{mg}$ on patient demand. O ne of the authors ( $\mathrm{MN}$ ), who was blinded to group allocation, evaluated the intensity of postoperatively pain using VAS at the first rescue analgesics request, and at $15,24,48$, and $72 \mathrm{hr}$ after the surgery at rest and on coughing. The time to first request and the number of times diclofenac was used in the first 24 $\mathrm{hr}$ after the surgery were recorded. If the patients experienced sever nausea and vomiting, this was treated with $10 \mathrm{mg}$ metoclopramide iv and noted. Side effects associated with flurbiprofen were recorded, if present.

All data are presented as mean \pm SD. D emographic data (age, height, weight, and duration of surgery) and the time to the first request for diclofenac were analyzed using one-way analysis of variance, followed by Fisher's protected least significant difference test. VAS and the number of requests for diclofenac among groups were analyzed by Kruskal-Wallis test. Incidence of adverse events was compared by chisquared analysis. $P$ values $<0.05$ were considered statistically significant.

\section{Results}

The three groups were comparable in pre- and intraoperative characteristics (Table). The time to first diclofenac request in the POST group was longer than in the CONT and PRE groups. The number of
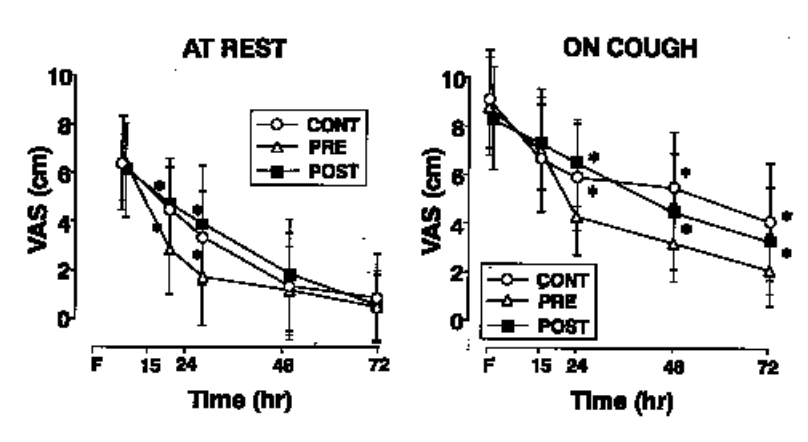

FI GU RE VAS scores for postoperative pain (M ean \pm SD). Compared with the CONT and POST groups, the PRE group showed lower VAS scores at rest at 15 and $24 \mathrm{hr}$ postoperatively and on coughing at 24,48 , and $72 \mathrm{hr}$ postoperatively. ${ }^{*} \mathrm{P}<0.05$ vs PRE.

F; Time of first diclofenac request. 
TAB LE Demographic and Perioperative D ata

\begin{tabular}{|c|c|c|c|}
\hline & $\begin{array}{l}\text { CON T } \\
(n=15)\end{array}$ & $\begin{array}{l}\text { PR E } \\
(n=15)\end{array}$ & $\begin{array}{l}\text { POST } \\
(n=15)\end{array}$ \\
\hline \multicolumn{4}{|l|}{ Preoperative } \\
\hline Age (yr) & $47 \pm 8$ & $46 \pm 6$ & $46 \pm 5$ \\
\hline H eight $(\mathrm{cm})$ & $152 \pm 6$ & $154 \pm 7$ & $156 \pm 7$ \\
\hline Weight (kg) & $51 \pm 10$ & $56 \pm 5$ & $59 \pm 7$ \\
\hline \multicolumn{4}{|l|}{ Intraoperative } \\
\hline D uration of surgery (min) & $71 \pm 18$ & $82 \pm 17$ & $88 \pm 21$ \\
\hline U rine output $\left(\mathrm{ml} \cdot \mathrm{min}^{-1}\right)$ & $2.0 \pm 1.0$ & $1.8 \pm 0.9$ & $1.6 \pm 0.9$ \\
\hline Blood loss $(\mathrm{g})$ & $255 \pm 228$ & $301 \pm 181$ & $269 \pm 139$ \\
\hline Sevoflurane (ml) & $29 \pm 8$ & $33 \pm 8$ & $31 \pm 7$ \\
\hline Vecuronium (mg) & $9.3 \pm 2.1$ & $10.3 \pm 1.7$ & $10.1 \pm 2.2$ \\
\hline Epidural lidocaine (mg) & $269 \pm 47$ & $252 \pm 45$ & $237 \pm 40$ \\
\hline \multicolumn{4}{|l|}{ Postoperative } \\
\hline Time to first diclofenac ( $\min )$ & $124 \pm 49$ & $128 \pm 36$ & $186 \pm 34^{*} \dagger$ \\
\hline No. of diclofenac in $24 \mathrm{hr}(\mathrm{n})$ & $3.0 \pm 0.8$ & $1.8 \pm 1.3^{*}$ & $2.0 \pm 1.2^{*}$ \\
\hline No. of patients with PONV (n) & 6 & 7 & 5 \\
\hline
\end{tabular}

M ean \pm SD or N umber. $* P<0.05$ vsCONT, $\dagger \mathrm{P}<0.05$ vsPRE.

diclofenac requests during the first $24 \mathrm{hr}$ after surgery was less in the PRE and POST groups than in the CONT group. Compared with the CONT and POST groups, the PRE group showed lower VAS scores at rest at 15 and $24 \mathrm{hr}$ postoperatively and on coughing at 24 , 48 , and $72 \mathrm{hr}$ postoperatively (Figure). The incidence of postoperative nausea and vomiting were not different among the groups (Table). No patients showed any adverse effects associated with flurbiprofen.

Discussion

D iclofenac requirement after abdominal hysterectomy was less in both flurbiprofen groups than in the control group. Moreover, preoperative administration of flurbiprofen showed lower postoperative VAS scores than postoperative administration, which indicated a preemptive analgesic effect with flurbiprofen.

The efficacy of preemptive analgesic treatment with N SAID s remains disputed. Elhaki and $\mathrm{N}$ afie ${ }^{6}$ showed that intravenous tenoxicam before induction of anesthesia reduced postoperative opioid consumption after Cesarean section. A recent report by Rømsing et al. ${ }^{7}$ also demonstrated that, for tonsillectomy, preoperative intravenous ketorolac reduced the postoperative use of fentanyl more than postoperative administration. In contrast, Buggy et al. ${ }^{8}$ showed that administration of diclofenac im prior to laparoscopic tubal ligation produced no additional benefit compared with postoperation administration. In our study, preoperative administration of flurbiprofen reduced postoperative pain more than postoperative administration during the $72 \mathrm{hr}$ period monitored, not only at rest, but also on coughing.
The inflammatory reaction in tissue damaged during surgery could provide a source of postoperative sensory signals and induce central sensitization. An injectable form of flurbiprofen has been made available by emulsifying lipid microspheres which have a high affinity to inflamed tissues. ${ }^{3}$ Swift et al. ${ }^{9}$ found that preoperative administration of flurbiprofen reduced the increase in tissue levels of immunoreactive bradykinin. Thus, we speculated that injectable flurbiprofen is a suitable N SAID to induce a preemptive effect.

The onset of the analgesic action of intravenous flurbiprofen occurs within 30 min of its administration, and lasts 5-12 $\mathrm{hr}^{3}$ Because we administered flurbiprofen 30 min before beginning surgery in the PRE group, its effects should have lasted throughout the operation in this group of patients. The dose of flurbiprofen was chosen on the basis of current recommendations. ${ }^{3,4}$

There was no reduction in the incidence of postoperative nausea and vomiting in the patients treated with flurbiprofen, although NSAIDs have been reported to produce antiemetic effects postoperatively. ${ }^{10} \mathrm{M}$ ikawa et al. ${ }^{3}$ also demonstrated that preoperative flurbiprofen is effective for postoperative pain relief but not for the prevention of emesis after pediatric strabismus surgery.

The NSAIDs are associated with an increase in bleeding time due to antiplatelet effects. However, with our single dose infusion of flurbiprofen, intraoperative blood losses in the flurbiprofen-treated and placebo groups were similar, and no adverse effect on postoperative bleeding was seen in any of the patients. These results are in agreement with other studies which found no significant increase in bleeding associated with NSAID administration. 1,2,6

We conclude that the intravenous administration of flurbiprofen during anesthesia is effective in reducing postoperative rescue analgesic requirement. M oreover, preoperative flurbiprofen will diminish postoperative pain in a preemptive manner.

\section{References}

1 Perttunen K, Nilsson E, K also E. I.v. diclofenac and ketorolac for pain after thoracoscopic surgery. $\mathrm{Br}$ J Anaesth 1999; 82: 221-7.

2 Tarkkila P, Saarnivaara L. Ketoprofen, diclofenac or ketorolac for pain after tonsillectomy in adults? $\mathrm{Br}$ J Anaesth 1999; 82: 56-60.

3 Mikawa K, N ishina K, Maekawa N, Shiga M, Obara $\mathrm{H}$. D ose-response of flurbiprofen on postoperative pain and emesis after paediatric strabismus surgery. $C$ an J Anaesth 1997; 44: 95-8. 
4 Tanaka S, Sonoda H, Nakabayashi K, N amiki A. Preoperative flurbiprofen provides pain relief after laparoscopic cholecystectomy. (Japanese) M asui 1997; 46: 679-83.

5 Woolf CJ, Chong M-S. Preemptive analgesia - treating postoperative pain by preventing the establishment of central sensitization. Anesth Analg 1993; 77: 362-79.

6 Elhakim M, N afie M. I.v. tenoxicam for analgesia during Caesarean section. Br J Anaesth 1995; 74: 643-6.

7 Rømsing J, Østergaard D, Walther-Larsen S, Valentin $\mathrm{N}$. Analgesic efficacy and safety of preoperative versus postoperative ketorolac in paediatirc tonsillectomy. Acta Anaesthesiol Scand 1998; 42: 770-5.

8 Buggy DJ, Wall C, Carton EG. Preoperative or postoperative diclofenac for laparoscopic tubal ligation. $\mathrm{Br}$ J Anaesth 1994; 73: 767-70.

9 Swift JQ, Garry MG, R oszkowski MT, H argreaves KM. Effect of flurbiprofen on tissue levels of immunoreactive bradykinin and acute postoperative pain. J Oral M axillofac Surg 1993; 51: 112-6.

10 Kokki H, Homan E, Tuovinen K, Purhonen S. Peroperative treatment with i.v. ketoprofen reduces pain and vomiting in children after strabismus surgery. Acta Anaesthesiol Scand 1999; 43: 13-8. 